Smith, R. E. \& Scott, H. M. (1965). F. Nutr. 86, 37.

Waterlow, J. C. \& Stephen, J. M. L. (1969). Proc. Nutr. Soc. 28, 234.

Williams, R. B. \& Chesters, J. K. (1970). Br. F. Nutr. 24, 1053.

Zimmerman, R. \& Scott, H. M. (1965). Y. Nutr. 87, 13.

\title{
Movements of ammonia following intraruminal administration of urea or casein
}

By Margaret I. Chalmers, Alice E. Jaffray and F. White, Rowett Research Institute, Bucksburn, Aberdeen $A B{ }_{2}{ }_{9} S B$

In considering the immediate responses to the ingestion of food in the ruminant we have not only to define the composition of the meal but also the state of the rumen fluid into which the ingested food is added. Every meal is modified by microbial action in the rumen. The host animal absorbs metabolites first from the rumen and then from the omasum, abomasum and intestines as a result of the digestion of the rumen contents passing through the alimentary tract. The ration fed over the previous few days determines the $\mathrm{pH}$ of therumen contents, its chemical composition, and the distribution of bacterial and protozoal species present. Into this predetermined fluid arrives a meal together with saliva. The rumen contents before the meal, the chemical and physical attributes of the meal and the salivary response it provokes are all variables which contribute to the immediate movement of metabolites.

In this paper we wish to consider the absorption of ammonia, a product of microbial digestion of protein and the end-product of urea hydrolysis. Ammonia toxicity can arise from feeding urea or ammonium salts but there is no evidence of ammonia poisoning from protein feeding even when the concentration of ammonia in rumen liquor reaches values of over $200 \mathrm{mg}$ ammonia-nitrogen per $100 \mathrm{ml}$ (Briggs, Hogan \& Reid, 1957). The difference between the two systems must lie in the relative importance of the rates of production and the routes of absorption of ammonia and the effect of different conditions upon them. In the discussion which follows, the term ammonia will be used to mean total ammonia; $\mathrm{NH}_{4}{ }^{+}$refers to ammonium ion and $\mathrm{NH}_{3}$ to free ammonia.

McDonald (I948) focused attention on the importance of ammonia production in the rumen and the ready absorption of ammonia from the rumen of the anaesthetized sheep, and his observations were confirmed by Chalmers, Cuthbertson \& Synge (1954). The first systematic investigation of ammonia metabolism was that of Lewis, Hill \& Annison (1957) using surgically prepared animals. They showed that, in conscious sheep, ammonia is absorbed from the rumen into the portal system and foundaclose correlation between changes in total ammonia concentration in the rumen and ammonia in portal blood. There was no evidence for any mechanism regulating absorption of ammonia and the authors concluded that ammonia transference was affected by simple diffusion through the rumen epithelium. Two observations made in this paper merit attention; firstly, "leakage of ammonia through 
the liver occurred over a range of ammonia levels and gradually increased as the rumen concentration increased', and secondly, 'the rumen ammonia concentration at which ammonia appeared in peripheral blood was not constant'. In a subsequent paper, Lewis (1959) observed that the normal level of blood ammonia in the sheep seemed to be somewhat higher than in non-ruminants. He then artificially raised the ammonia concentration in the rumen by introducing ammonium acetate at hourly intervals, toxicity was related direct to the circulating blood ammonia level, critical around $0.8 \mathrm{mg}$ ammonia-N/100 ml. Hogan (1961) studied the transport of ammonia across the rumen epithelium in acute experiments on anaesthetized sheep. The rumen was isolated by ligating the oesophagus and the reticulo-omasal orifice, and the carotid artery, jugular and posterior rumen veins were exposed. The rumen was emptied, washed out, and refilled with ammonium sulphate solutions in buffer at $\mathrm{pH} 6.5$ or 4.5 . Although increase in rumen ammonia concentrations at $\mathrm{pH} 6.5$ were accompanied by increased concentrations in ruminal vein blood, the rate of transport of ammonia from the rumen was not altered with changes in concentration at $\mathrm{pH} 4.5$. It was suggested that one mechanism for the transport of ammonia across the rumen epithelium is by diffusion as $\mathrm{NH}_{3}$. The concentration of $\mathrm{NH}_{3}$ can be calculated by the Henderson-Hasselbach equation, knowing the $\mathrm{pH}$ and total ammonia concentration in the rumen liquor. Hogan also noted that at higher concentrations of ammonia in the rumen the rate of blood flow was reduced in the ruminal vein. Coombe, Tribe, \& Morrison (1960) also concluded that maximum ammonia levels reached in the rumen were not sufficient to explain the differences between animals in their reaction to ingested urea. Rumen $\mathrm{pH}$ was also important in so far as toxicity is concerned. Signs of toxicity were observed when the $\mathrm{pH}$ in the rumen was above $7 \cdot 3$ and they explained the increase in peripheral blood ammonia as inability of the liver to detoxicate the increased quantity of ammonia arising from the increased rate of its absorption at high $\mathrm{pH}$.

The effect of ruminal $\mathrm{pH}$ on ammonia absorption was studied in goats by Yoshida $\&$ Nakamura $(1963)$, again in acute experiments under anaesthesia. Urea was administered intraruminally and the rumen $\mathrm{pH}$ altered by the introduction of acetic acid or potassium hydroxide. The ammonia concentrations were measured at intervals in sections of the alimentary tract, and in blood from ruminal, intestinal, and jugular veins and the carotid artery. No increment of ammonia was found in the alimentary tract beyond the rumen; absorption of ammonia from the rumen varied direct with the $\mathrm{pH}$, and was considered to be diffusion of unionized ammonia. The addition of molasses, sucrose, glucose, or $\mathrm{CO}_{2}$ bubbled into rumen liquor containing urea suppressed the $\mathrm{pH}$ rise and ammonia toxicity.

A different method was used by Gärtner and Engelhardt (1964) who measured the rate of disappearance of $\mathrm{NH}_{3}$ and $\mathrm{NH}_{4}{ }^{+}$from the rumen. Urea or ammonium salts were administered intraruminally and the concentrations of $\mathrm{NH}_{3}$ and $\mathrm{NH}_{4}{ }^{+}$ were calculated from $\mathrm{pH}$ and total ammonia concentration; the rumen volume was measured by polyethyleneglycol (PEG). The authors concluded that only unionized ammonia molecules were able to penetrate the ruminal wall proportional to their concentration, a correlation which held good for $\mathrm{pH} 6.9$ to 7.5 but not from $\mathrm{pH} 6.75$ 
to 6.9. More recently, Mooney \& O'Donovan (I970) measured ammonia transport in both directions across the rumen wall using the Ussing apparatus. At $\mathrm{pH} 7 \cdot 0$, equilibrium was reached with equal concentrations of ammonia on both sides of the membrane and, when the $\mathrm{pH}$ was lowered on one side of the membrane, equilibrium was reached with a greater concentration of ammonia on the acid side. They put forward the hypotheses that ammonia transport across the rumen wall in both directions is passive and that the membrane is more permeable to $\mathrm{NH}_{3}$ than to $\mathrm{NH}_{4}{ }^{+}$.

The evidence assembled so far suggests that ( $\mathrm{I}$ ) there is an increase in the transport of ammonia into ruminal veins with increasing concentrations of ammonia in the rumen,(2) movement of ammonia is accelerated at rumen $\mathrm{pH}$ above $7 \cdot 3$ due to the increased proportion of $\mathrm{NH}_{3}$ and (3) ammonia toxicity is the direct result of the increased concentration of ammonia in portal vein blood overloading the liver and causing a rise in the ammonia concentration of circulating peripheral blood.

Ambo, Shiga, Yamamoto, Shibita, Watanabe, Tsuda \& Umezu (I967) studied the capacity of the liver to detoxicate ammonia entering via the portal blood. Goats were given hay and concentrates before the experiment. Ammonium carbonate solutions adjusted to $\mathrm{pH} 7 * 4$ were constantly infused through a catheter into the portal vein at a rate of $100 \mathrm{ml}$ per $\mathrm{h}$ : a different animal was used for each ammonia concentration infused. Ammonia and urea were determined in jugular blood at hourly intervals; values ranged from 0 to $3^{6 \cdot \mathrm{I}} \mathrm{mg}$ ammonia-N per $\mathrm{h}$ per $\mathrm{kg}$ bodyweight. No significant increase in jugular blood ammonia was found with infusion rates up to $30 \mathrm{mg}$ ammonia- $N$ per $\mathrm{h}$ but at infusion rates of 33 and $36 \mathrm{mg}$ ammonia- $\mathrm{N}$ there was a sharp rise in jugular blood ammonia, toxic symptoms developed and death occurred within a few hours. These experiments measured liver function only and we have used the data to calculate the threshold value for ammonia in the liver, assuming the blood flow in portal vein to be $500 \mathrm{ml}$ per min (Bensadoun $\&$ Reid, 1962). The concentration of ammonia in portal blood would require to exceed $4.8 \mathrm{mg}$ per $100 \mathrm{ml}$ for an animal of $50 \mathrm{~kg}$ body-weight before ammonia toxicity could be considered as the direct result of overloading the liver. Linzell, Setchell \& Lindsay (I97I), using a liver perfusion technique, found that $\mathrm{I}_{50} \mathrm{mg}$ ammonia per $\mathrm{h}$ per $100 \mathrm{~g}$ liver was the limit of the detoxicating capacity; at infusion rates above that, ammonia was in excess. This is equivalent to a concentration of $6-7 \mathrm{mg}$ ammonia per $100 \mathrm{ml}$ portal blood.

\section{Experimental studies}

During the last 2 years we have been studying the movements of ammonia into the blood of the portal system following intraruminal administration of urea or casein. Portal blood ammonia has never exceeded $2.5 \mathrm{mg}$ per $100 \mathrm{ml}$ blood even in cases of severe toxicity from urea: the rate of blood flow would have to be twice that estimated by Bensadoun \& Reid (1962) to account for toxicity solely on the basis of liver overload. In view of venoconstriction in splanchnic vessels brought about by ammonia (Hogan, 196r; Greig \& Boddie, 1942), an increase in blood flow is unlikely to occur. For this and reasons which will be discussed later we consider that in none of our experiments has the liver threshold for ammonia been exceeded. 
Our standard experimental procedure is to stabilize the ewe on a basal maintenance ration of cereals and hay, insert cannulas into the right ruminal, anterior mesenteric or portal veins and allow the animal to recover fully from the operation (White, Wenham, Hughes, Mathieson \& Chalmers, 1969). The sheep can then be used for a series of experiments at weekly intervals giving within-sheep comparisons on a conscious animal with a normally functioning rumen. The sheep is fed a ration of $15^{\circ} \mathrm{g}$ cereals in the morning and $90 \mathrm{~min}$ later the supplement is administered direct into the rumen. Rumen liquor and blood from the jugular and two veins of the portal system are monitored for movements in $\mathrm{pH}$, urea and ammonia over a period of hours.

A comparison between urea and casein as a source of ruminal ammonia is shown in Fig. $I$ and the corresponding blood picture in Fig. 2. The highest total ammonia

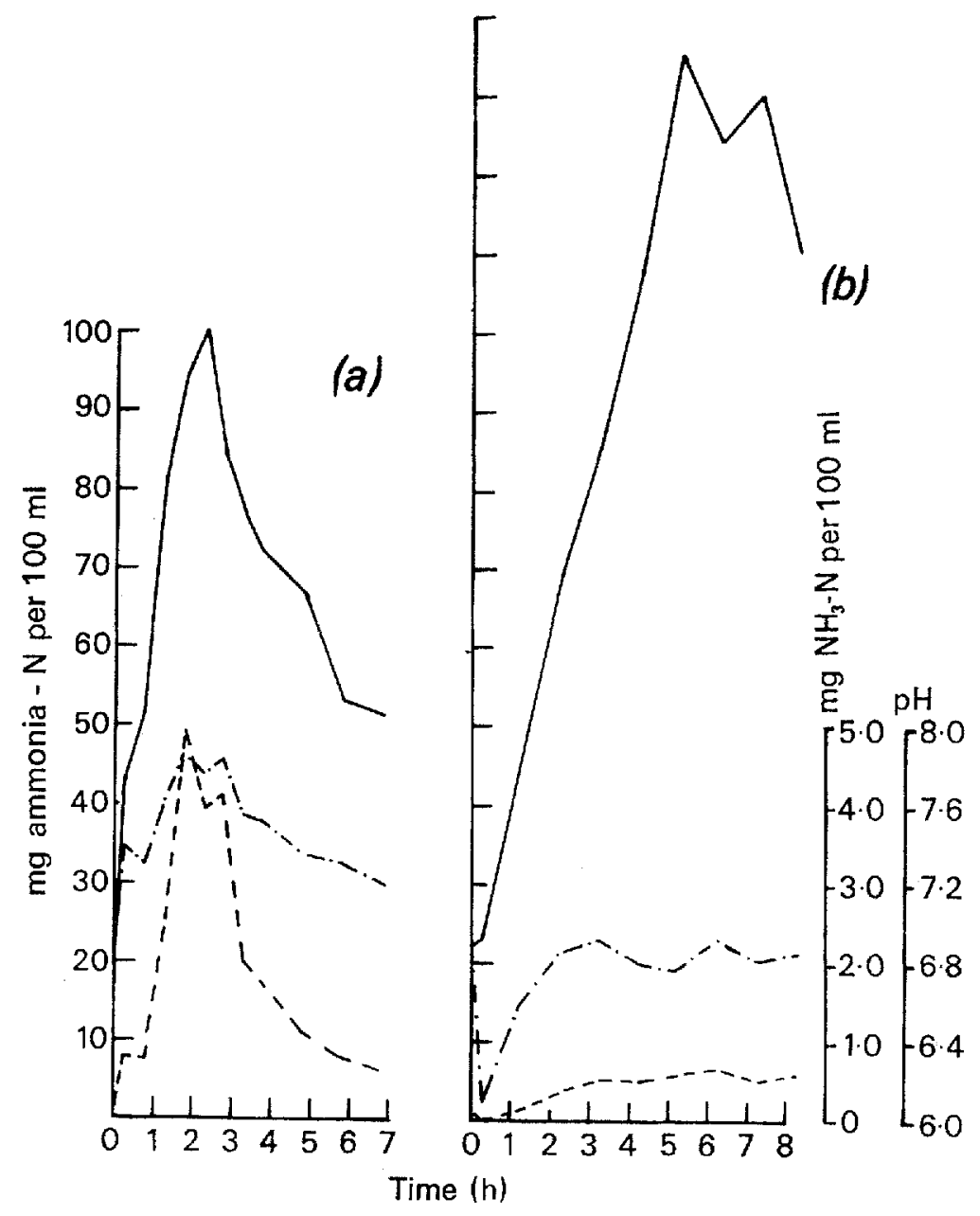

Fig. I. Comparison between urea and casein as a source of ruminal ammonia. A Cheviot ewe (3509) was given $150 \mathrm{~g}$ mixed cereals $90 \mathrm{~min}$ prior to intraruminal administration of $20 \mathrm{~g}$ urea $(a)$ or $200 \mathrm{~g}$ casein $(b)$ at time $0 .-\longrightarrow$, total ruminal ammonia; -.... rumen $\mathrm{pH} ;-\ldots-\mathrm{NH}_{3}$ concentration, calculated by Henderson-Hasselbach equation. 


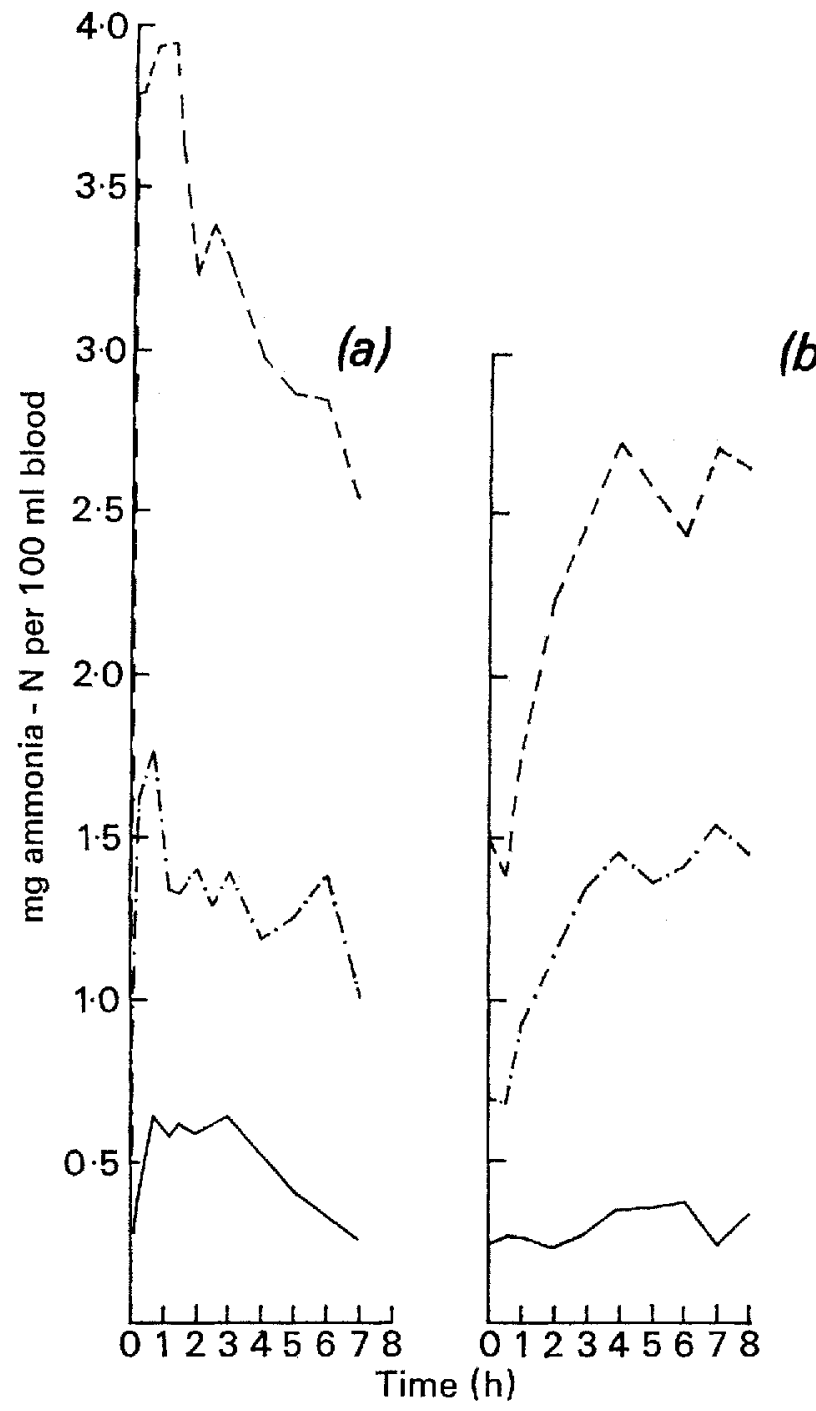

Fig. 2. Blood ammonia concentrations of a Cheviot ewe (3509) given (a) urea or (b) casein. - - -, ruminal vein; -.--- intestinal vein; - jugular vein.

concentration in the rumen is produced from casein and yet the ammonia concentration in the jugular vein remains low. The movement of rumen $\mathrm{pH}$ after casein administration is quite different from that following urea administration. The shape of the $\mathrm{pH}$ curve is reproduced in the movement of ammonia concentration in jugular vein blood. The pattern of absorption of ammonia into the portal system in the two systems is different, the rise in ammonia concentration in the ruminal vein in the first 15 min after giving urea can be explained in part by the rapid rise in rumen ammonia concentration but the rapid rise in the intestinal vein requires some other explanation. The ammonia cannot have been absorbed from intestinal contents as $\mathrm{I}_{5} \mathrm{~min}$ is too short a time-interval for rumen digesta to reach the jejunum 
in amounts sufficient to account for the rise. The difference in rumen $\mathrm{pH}$ represents a rise in $\mathrm{NH}_{3}$ concentration of the order of fifty times the baseline concentration for urea compared with five times that for casein. If it is postulated that $\mathrm{NH}_{3}$ rapidly diffuses through the rumen epithelium into the peritoneum then any vein in the vicinity of the rumen could trap the ammonia and transport it to the liver. We have observed a rapid rise of ammonia in caecal vein as well as in intestinal vein I5 min after administering urea.

The effect of rumen $\mathrm{pH}$ on jugular ammonia concentration was studied in four experiments on one sheep; $O, 10,20$, or $40 \mathrm{ml}$ acetic acid were administered intraruminally with $20 \mathrm{~g}$ urea in $200 \mathrm{ml}$ water. The addition of acid did not significantly alter the rise in total ammonia concentration in the rumen but effectively controlled the rise in $\mathrm{pH}$. The ammonia concentration in jugular vein follows the rumen $\mathrm{pH}$ (Fig. 3a): the lower the rumen $\mathrm{pH}$ the lower the jugular blood ammonia concentration. A particular point to notice is the drop in jugular ammonia at $15 \mathrm{~min}$ when the rumen $\mathrm{pH}$ dropped to 5.3 on addition of $40 \mathrm{ml}$ acetic acid. If all the ammonia in jugular blood first traversed the liver, then it is difficult to explain a drop in jugular blood ammonia concentration at a time when rumen ammonia concentration is rising. The correlation of rumen $\mathrm{pH}$ with the immediate rise in the ammonia concentration in blood from the intestinal vein is shown in Fig. $3 \mathrm{~b}$. When the rise in rumen $\mathrm{pH}$ was controlled by the addition of acid, the ammonia concentration in blood from the intestinal vein was decreased at $15 \mathrm{~min}$.

The immediate rise of ammonia concentration in intestinal and caecal veins implies that ammonia crosses to the veins via peritoneal fluid. Since peritoneal fluid drains into the thoracic duct (Rusznayák, Földi \& Szabó, 1967) and the thoracic duct empties into a large vein (jugular, brachial or anterior vena cava) just anterior to the right auricle, ammonia could arrive into the venous blood without traversing the liver. A rise in jugular blood ammonia could thus occur even in situations where the capacity of the liver to convert ammonia to urea is not overloaded.

We have consistently observed a rising jugular blood ammonia corresponding to a rising $\mathrm{NH}_{3}$ concentration in the rumen following the administration of urea. If all ammonia travelled via the portal system to the liver no rise in peripheral blood ammonia would occur in spite of a rising $\mathrm{NH}_{3}$ concentration until the liver threshold was exceeded.

A correlation between ammonia concentration in rumen contents and peripheral blood was shown in the papers of Lewis et al. (1957) and Ambo et al. (1967). Lewis et al. expressed some reservations on the completeness of the correlation, the majority of their figures were from sheep fed casein or casein hydrolysate over a period of time and the rumen $\mathrm{pH}$ (not recorded) would be in the range 6.0 to 6.5 . The data used by Ambo et al. were from experiments on goats in which the rumens were emptied and washed out before the introduction of ammonium carbonate solutions. We have used the results from seventy experiments on twenty sheep to plot ruminal ammonia concentration against jugular ammonia concentration, dividing the data into those when rumen $\mathrm{pH}$ was below 6.9 (Fig. 4a) and those when rumen $\mathrm{pH}$ was above 6.9 (Fig. $4 \mathrm{~b}$ ). There is some correlation at 
Vol. 30
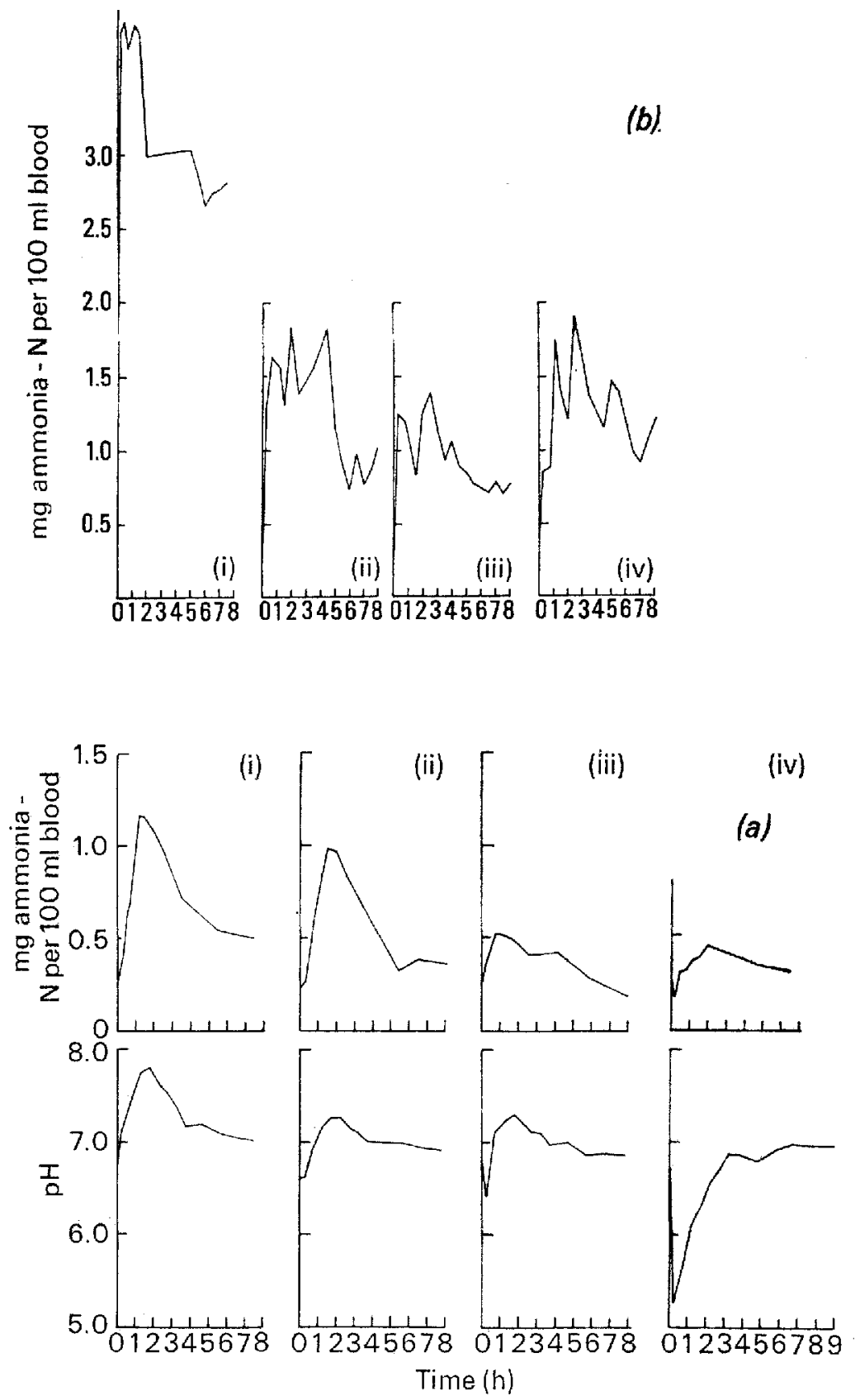

Fig. 3. (a) Correlation between rumen $\mathrm{pH}$ and jugular blood ammonia in a Cheviot ewe (3505) given I $50 \mathrm{~g}$ mixed cereals $90 \mathrm{~min}$ prior to intraruminal administration of (i) $20 \mathrm{~g}$ urea (ii) $20 \mathrm{~g}$ urea $+\mathrm{io} \mathrm{ml}$ acetic acid (iii) $20 \mathrm{~g}$ urea $+20 \mathrm{ml}$ acetic acid (iv) $20 \mathrm{~g}$ urea $+40 \mathrm{ml}$ acetic acid; (b) ammonia concentrations in the intestinal vein.

rumen $\mathrm{pH}$ below $6 \cdot 9$, but this breaks down at the higher $\mathrm{pH}$ range. If we then use only the data when ruminal ammonia concentration was between 80 and $100 \mathrm{mg}$ ammonia- $\mathrm{N}$ per $100 \mathrm{ml}$ rumen liquor, and plot rumen $\mathrm{pH}$ against jugular blood 


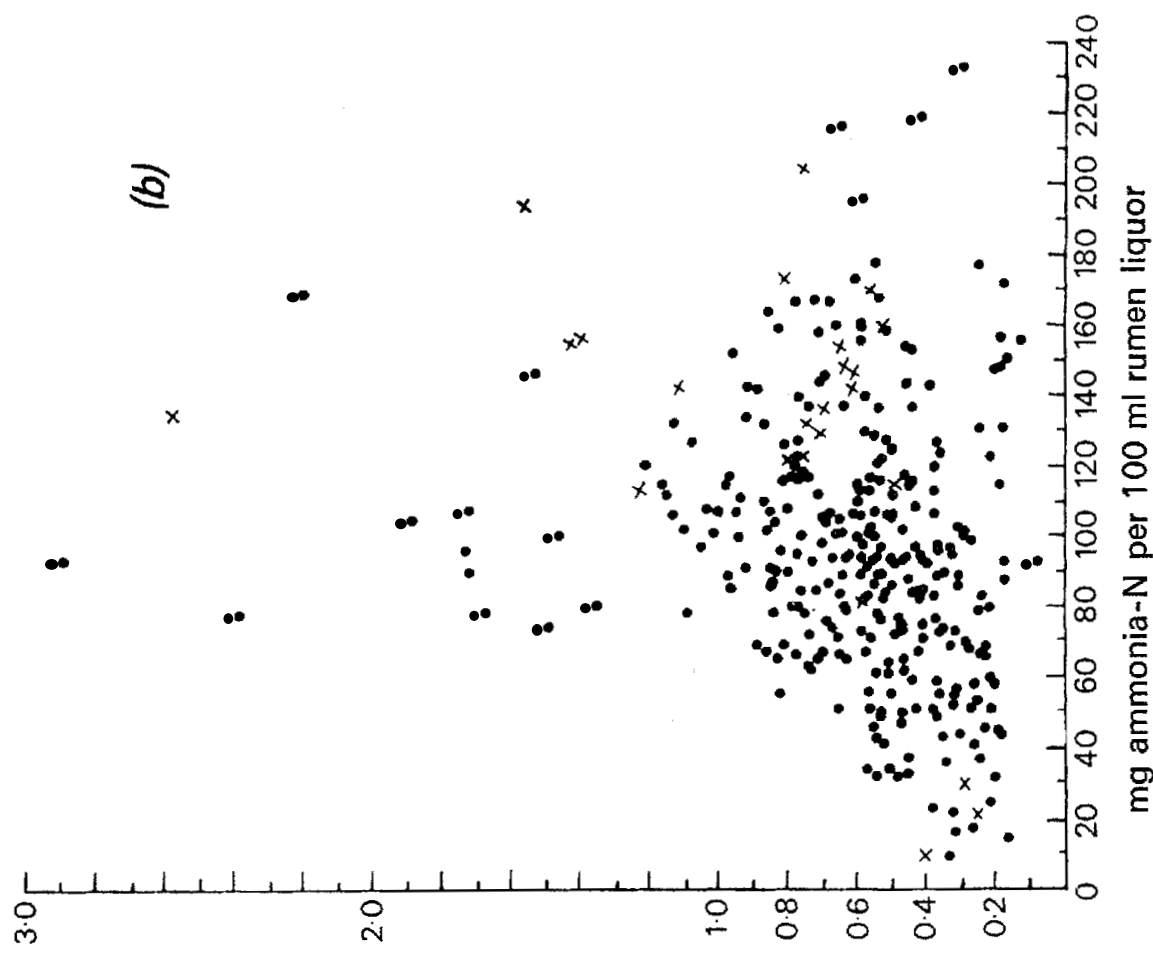

poolq de!n6n! ju 001 sad $N$-e!nowme $6 u$
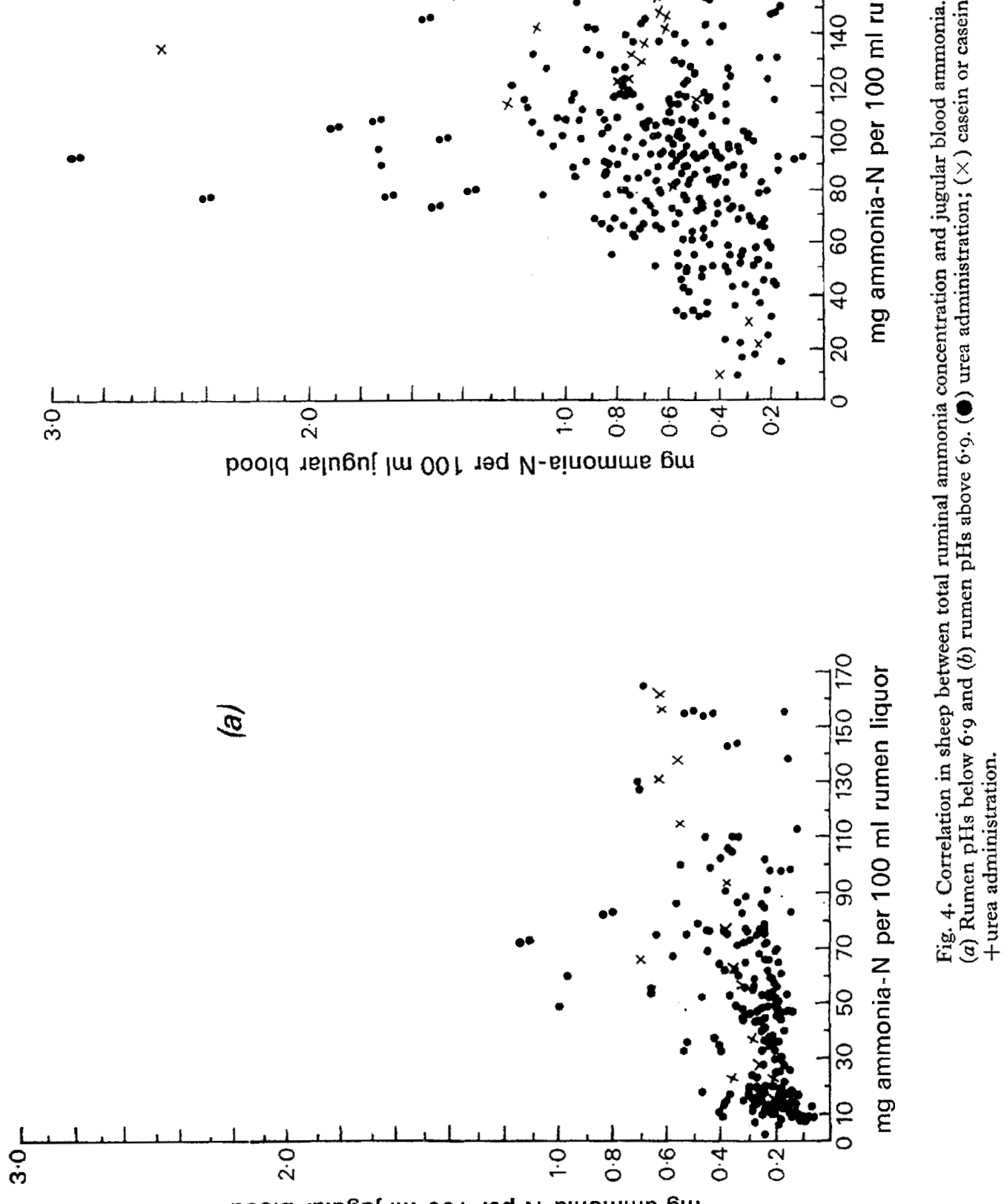

poolq sejn6n! ju oOL dəd N-e!uousue bu 
ammonia (Fig. 5), there is an obvious effect of rumen $\mathrm{pH}$ on the movement of ammonia into venous blood.

To test our hypothesis that ( 1 ) the ammonia diffusing from the rumen into peritoneal fluid is $\mathrm{NH}_{3}$ and dependent on rumen $\mathrm{pH}$, and (2) the jugular vein derives

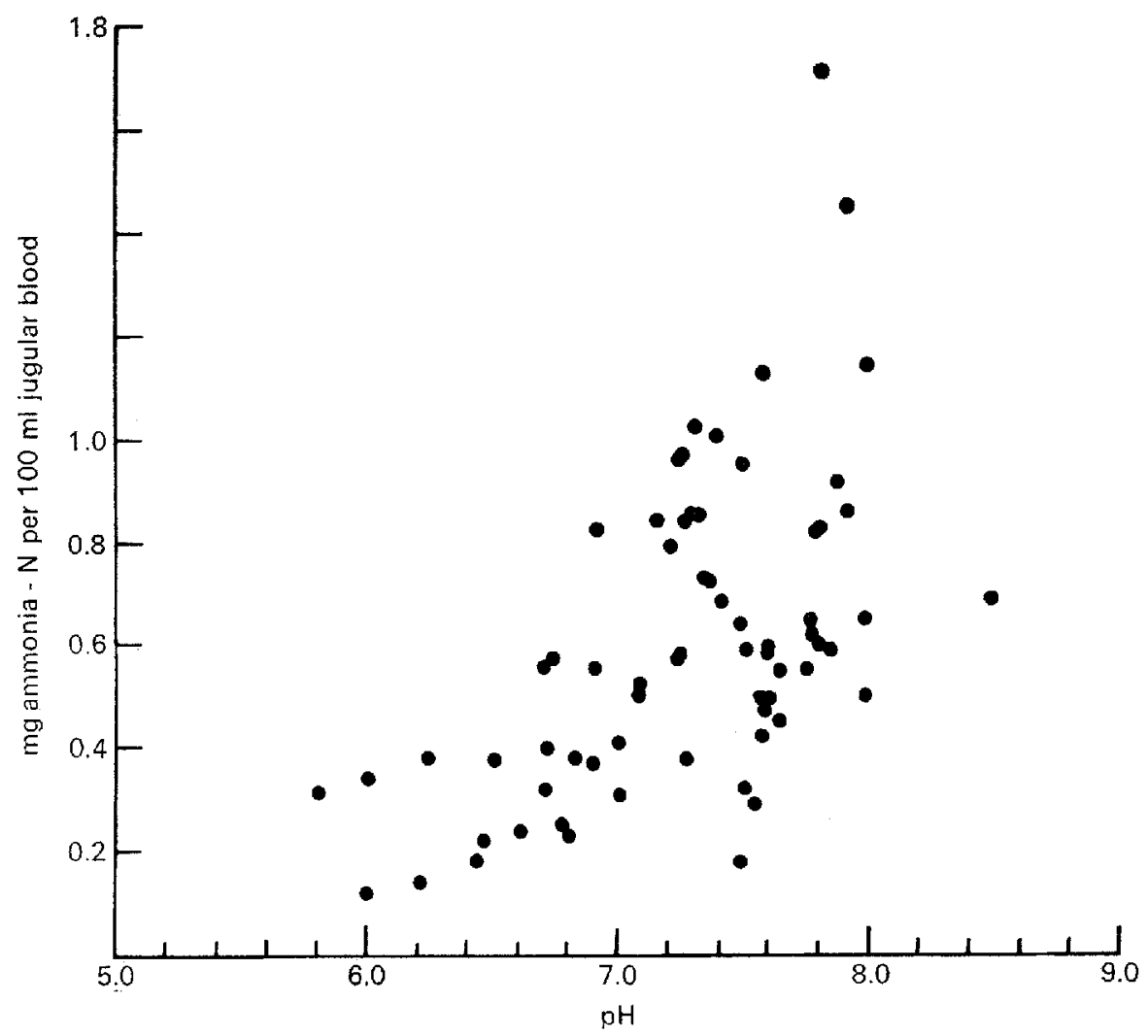

Fig. 5. Correlation in sheep between rumen $\mathrm{pH}$ and jugular blood ammonia. Total ruminal ammonia concentration for all points lie between 80 and $100 \mathrm{mg}$ ammonia-N per $100 \mathrm{ml}$ rumen liquor.

some ammonia from a route other than that through the liver, a sheep was fitted with plastic cannulas, opening into the peritoneal cavity, one high up in the right flank and the other in the umbilical region. Heparinized Krebs-Ringer solution was run into the peritoneal cavity through the top cannula to provide a reservoir of liquid for a series of samples. After an equilbration period of $30 \mathrm{~min}$ to I h, assessed by the constancy of urea concentrations in liquor and blood, $25 \mathrm{~g}$ urea with or without acetic acid, were introduced into the rumen, and rumen contents, jugular blood and peritoneal liquor monitored for ammonia and urea. The correlation of rumen $\mathrm{pH}$ with the movement of ammonia into the peritoneum and jugular blood is shown in Fig. 6. On basal ration alone the ammonia concentration in peritoneal liquor is higher than that in jugular blood (a). When $25 \mathrm{~g}$ urea were introduced into the rumen, the rumen $\mathrm{pH}$ increased, as did the concentration of ammonia in peritoneal liquor, after which there was a rise in jugular blood ammonia (b). In the next 

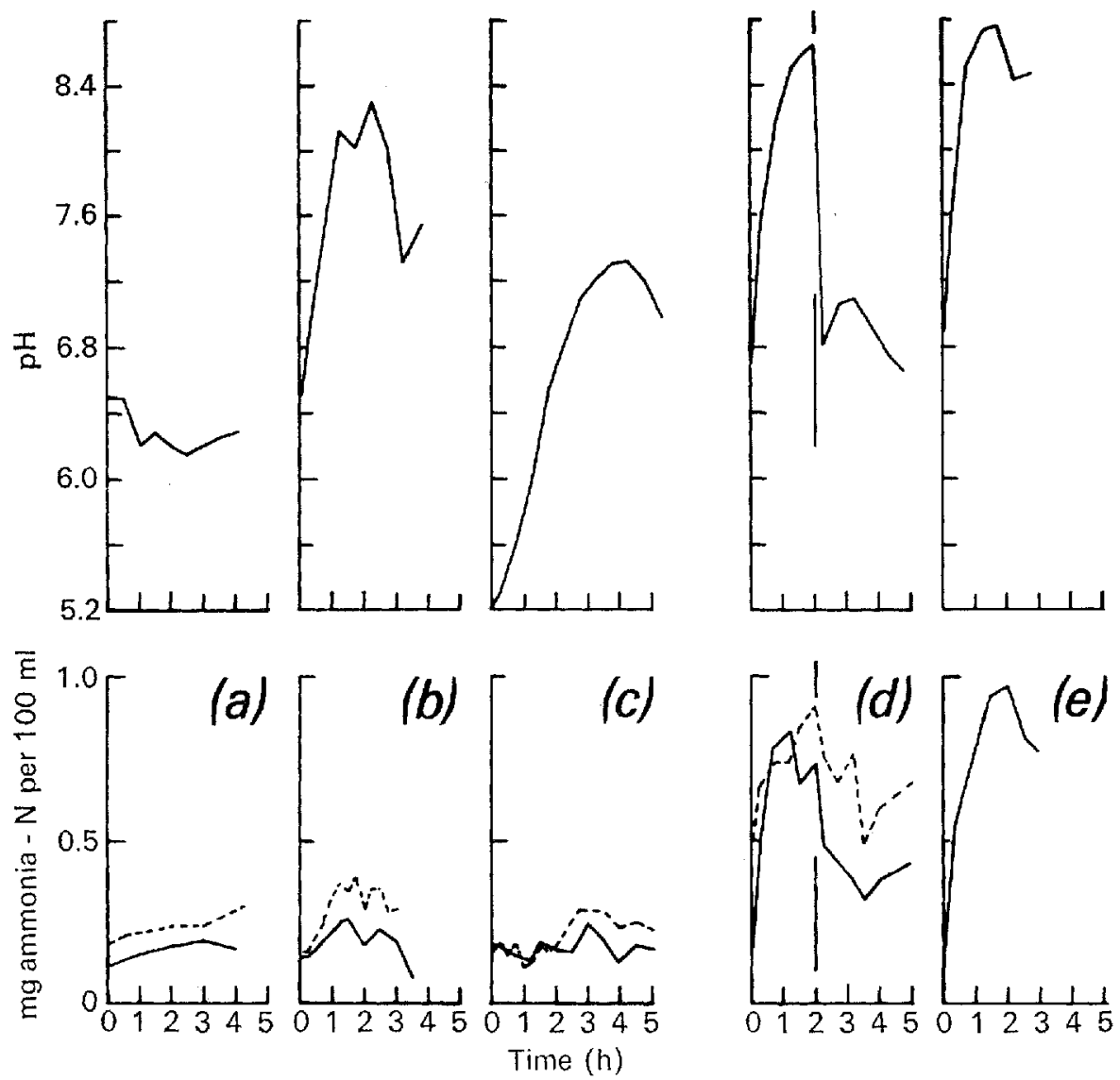

Fig. 6. Relationship in a Cheviot ewe (4998) between rumen pH and ammonia concentration in peritoneal liquid - - - and jugular blood 8) between rumen $\mathrm{pH}$ and ammonia concentration in peri-
(a) No urea; $(b) 25 \mathrm{~g}$ urea; $(c)$ Io $\mathrm{ml}$ acetic acid in rumen $45 \mathrm{~min}$ before $25 \mathrm{~g}$ urea $+\mathrm{I} \mathrm{ml}$ acetic acid; $(d) 25 \mathrm{~g}$ urea at time $0,30 \mathrm{ml}$ acetic acid at $2 \mathrm{~h} ;(e) 25 \mathrm{~g}$ urea.

The ewe was given $150 \mathrm{~g}$ mixed cereals $90 \mathrm{~min}$ prior to the intraruminal administration of $25 \mathrm{~g}$ urea at time 0 . Krebs-Ringer solution was run into the peritoneum in $(a),(b),(c)$ and $(d)$.

experiment, acetic acid was introduced into the rumen $\mathrm{I} h$ prior to administering urea to ensure that the rumen fluid was acid (c). The ammonia concentration of peritoneal liquor was low until the rumen $\mathrm{pH}$ rose to 6.8 and the ensuing increase of ammonia concentration was followed by a rise in jugular blood ammonia. In another experiment, acid that was introduced into the rumen $2 \mathrm{~h}$ after the administration of urea (d) caused an immediate drop in the ammonia concentration of both peritoneal liquor and jugular blood ammonia whereas the total ammonia concentration in the rumen fluid remained over $130 \mathrm{mg}$ ammonia-N per $100 \mathrm{ml}$. The rise in jugular blood ammonia from $25 \mathrm{~g}$ urea was greatest when the sheep had no liquid added to the peritoneum (e), indicating that the presence of a large volume of liquid must diminish the movement of ammonia across the peritoneum into venous blood. 


\title{
Conclusion
}

This series of experiments is consistent with the hypothesis presented that $\mathrm{NH}_{3}$ diffuses rapidly from the rumen and that a portion of this ammonia passes into peritoneal fluid and reaches the jugular vein without traversing the liver.

\section{REFERENCES}

Ambo, K., Shiga, A., Yamamoto, S., Shibita, F., Watanabe, Y. S., Tsuda, T. \& Umezu, M. (1967). Tohoku F. agric. Res. 18, 257.

Bensadoun, A. \& Reid, J. T. (r962). F. Dairy Sci. 45, 540.

Briggs, P. K., Hogan, J. P. \& Reid, R. L. (I957). Aust. F. agric. Res. 8, 674.

Chalmers, M. I., Cuthbertson, D. P. \& Synge, R. L. M. (1954). F. agric. Sci., Camb. 44, 254.

Coombe, J. B. Tribe, D. E. \& Motrison, J. W. C. (1960). Aust. $\mathscr{7}$. agric. Res, II, 247.

Gärtner, K. Van \& Engelhardt, W. v. (1964). Di. tierärztl. Wschr. 7I, 57.

Greig, J. R. \& Boddie, G. F. (editors) (I942). Hoare's Veterinary Materia Medica and Therapeutics p. I I9. London: Baillière, Tindall \& Cox.

Hogan, J. P. (г 961 ). Aust. F. biol. Sci. 14, 448.

Lewis, D. (1959). F. agric. Sci., Camb. 55, I.

Lewis, D., Hill, K. J. \& Annison, E. F. (I957). Biochem. F. 66, 587.

Linzell, J. L., Setchell, B. P. \& Lindsay, D. B. (1971). Q. $\mathscr{~ I l ~ e x p . ~ P h y s i o l . ~ 5 6 , ~} 53$.

McDonald, I. W. (I948). Biochem. F. 42, 584 .

Mooney, P. \& O'Donovan, D. J. (1970). Biochem. f. (In the Press.)

Rusznayák, I., Földi, M. \& Szabó, K. (1967). Lymphatics and Lymph Circulation 2nd ed. London: Pergamon Press.

White, F., Wenham, G., Hughes, A. D., Mathieson, J. \& Chalmers, M. I. (1969). Proc. Nutr. Soc. 28, $60 \mathrm{~A}$.

Yoshida, J. \& Nakamura, R. (I963). Fap. F. zootech. Sci. 34, 275.

\section{Some aspects of the digestion of proteins}

\author{
By J. W. G. Porter and B. A. Rolls \\ National Institute for Research in Dairying, Shinfield, Reading $R_{2}{ }_{9} A T$
}

Recent developments in analytical techniques have allowed more detailed studies to be made of the course of protein digestion. In this paper we consider some aspects of studies on the extent to which the behaviour of a food protein in the gastro-intestinal tract may be related to its digestibility and amino acid composition, and, ultimately, to its biological usefulness. Wider aspects of protein digestion have been reviewed by Gitler (1964), Rogers \& Harper (1966) and Crane (1969).

Proteins differ in their susceptibility to digestion but the principal stages have been clearly established. Ingested food is stored in the stomach where it is moistened, softened and mixed with $\mathrm{HCl}$ and pepsins, the combination of which results in denaturation of native proteins and their partial or complete solubilization. The chyme passes into the duodenum as protein or large peptides where it is subjected to the sequential action of the peptidases deriving from the pancreatic and intestinal juices, yielding fragments which may be absorbed by the intestinal mucosa and made available to the animal through the portal circulation. There are considerable differences in the time-course of the breakdown and assimilation of individual proteins and even more marked differences after damage by heating. 